\title{
POSTUROGRAPHIC TESTS OF CANDIDATES FOR MILITARY PILOTS
}

\author{
Wiestaw Mastowski", Tadeusz Opara**, Michat BureK ${ }^{*}$ \\ * Katedra Awioniki i Systemów Sterowania, Wydział Lotnictwa, Wyższa Szkoła Oficerska Sił Powietrznych \\ (Department of Avionics and Control Systems, Faculty of Aeronautics, Polish Air Force Academy), 08-521 Dęblin, \\ ul. Dywizjonu $303 \mathrm{nr} 35$ \\ *** Instytut Budowy Maszyn, Wydział Mechaniczny, Uniwersytet Technologiczno-Humanistyczny im. Kazimierza \\ Pułaskiego (Institute of Machine Building, Faculty of Mechanical Engineering, Kazimierz Pulaski University of \\ Technology and Humanities in Radom), 26-600 Radom, ul. Krasickiego 54 \\ w.maslowski@wsosp.pl,t.opara@uthrad.pl,m.burek@wsosp.pl
}

\begin{abstract}
One of the many elements of the process of qualifying the candidates for military aircraft pilots is the assessment of the correct functioning of their body balance system, responsible, inter alia, for spatial orientation during a flight. That system continuously controls the spatial position of the center of body mass. To measure that value directly is a complex metrological task. That is why an equivalent measure is used in tests of standing posture stability, i.e. the position of a projection of the center of mass on a supporting plane.

Quantitative information determining the characteristics of the body balance system may be obtained in posturographic tests, which include measurement, recording and assessment of the trajectory of a projection of the examined person's center of body mass.

At the preliminary stage, examined were nineteen candidates for fighter pilots (one woman and 18 men), students of the Polish Air Force Academy in Dęblin.

Based on the conducted measurements of the body mass center position and the stabilographic tests, the correctness of their balance system performance was assessed. The article discusses the examination methodology, presents measurement results and conclusions.

Keywords: posturography, body mass center position, balance system, force platform.
\end{abstract}

\section{INTRODUCTION}

The balance system works based on information obtained from the three sensory routes: vestibular, visual and proprioceptive ones (fig. 1) [1, 2]. 


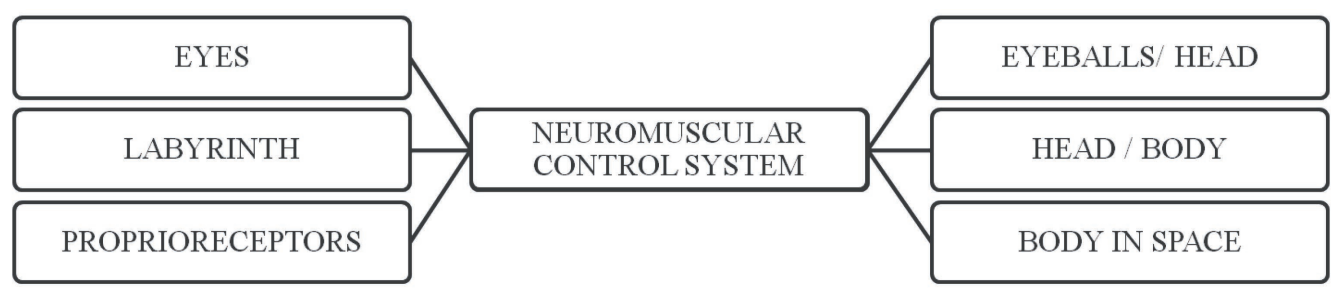

Fig. 1. Balance system functioning diagram $[1,2]$

The vestibular organ is located in the inner ear and makes the balance system responsible for keeping a vertical body posture and for spatial orientation. Its correct functioning relates to the cooperation of the peripheral and central nervous systems. The primary functions of the vestibular system include:

- reception and integration of the feeling of movement and the force of gravity,

- integration of reflexes related to the body mass center position,

- keeping balance,

- keeping an image on the retina while observing an object in motion.

Keeping spatial orientation is a psychic activity, closely related to perception, which manifests itself as a process of realizing one's body position. Gravity receptors and the organ of vision have a big influence on spatial orientation. When flying an aircraft without seeing the ground (at night, in clouds), information obtained from the gravity receptors alone may be insufficient to properly identify the position in space. In such a situation, it might happen that the pilots will perform the flight in a reversed position, with their heads down, while believing that their body position is correct. The phenomenon of spatial disorientation results from the limited adaptation capabilities of human senses, and the way information coming from those is processed.

The ability to keep balance and orientation in space in situations of dynamic position changes is an individual trait. Possibilities to improve it by training do exist, but are limited. The primary method of assessing the qualifications of candidates for pilots (especially of high-maneuvering aircrafts) is the system of verification tests.

\section{METHOD OF MEASURING THE POSITION OF THE EXAMINED PERSON'S MASS CENTER PROJECTION}

Maintaining a stable vertical posture is a result of a person's continuous functioning of the balance system. The quantitative assessment of that process is carried out in posturographic tests, which consist in recording minor movements of the examined person's center of mass (COM) $[3,5-10]$.

It is difficult to measure the value directly. That is why in tests of vertical posture stability, an equivalent measure is usually used, being the position of the projection of the center of mass on the posturograph plane, i.e. the position of the center of pressure (COP) of the feet on that plane. That point is located inside the outline of the feet (fig. 2). 


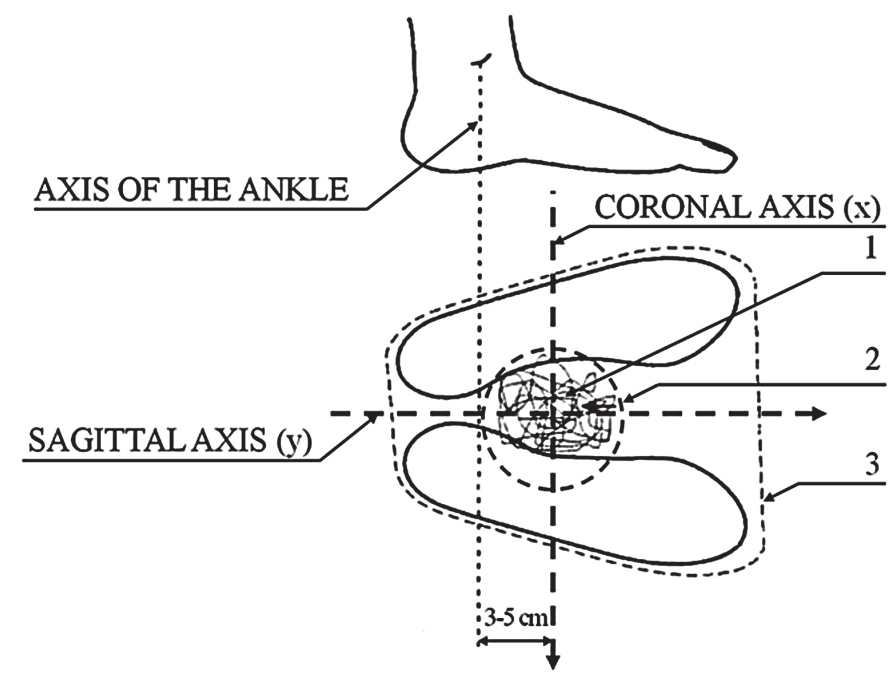

Fig. 2. Typical trajectory of the projection of a person's center of mass in a vertical position on the measurement system plane $(1$ - trajectory of the center of mass projection when standing freely, 2 - outline of the center of mass projection line, 3 - envelope of the feet support area)

From the human motion biomechanics standpoint, the ability of vertical position stabilization is about minimizing body swaying (the "front-back" and "left-right" tilting) so that the projection of the center of mass does not move outside of the stability limit set by the envelope of the feet support area (fig. 2) [3].

When analyzing the trajectory of the projection of an examined person's center of mass, it is possible to:

- draw conclusions as to the total efficiency of the balance system;

- evaluate the roles of individual sensory mechanisms in keeping a vertical posture by way of changing input signals: e.g. closed eyes or supporting plane vibrations.

An analysis of coordinates of the projection of an examined person's center of mass makes it possible to:

- evaluate the impact of factors causing imbalance (in the report by the international working team Kellogg of 1987, over a hundred causes of imbalance were cataloged, with a significant part of those being nervous factors causing disorders of body biomechanics [1]);

- evaluate the effectiveness of the balance system in different environmental conditions;

- control the process of changes to the ability of keeping balance, which take place as a consequence of a therapy or training.

The projection of the center of mass moves on the platform surface within the wheel, of which center marks the beginning of the coordinate system. In the Cartesian system:

- direction $(x)$ sets the frontal front-to-back axis ("left-right" tilting);

- direction (y) sets the sagittal axis running in the medial body plane ("front-back" tilting). 
The idea of defining the position of the center of mass projection consists in measuring the signal from reaction forces in point of support of the rigid horizontal plane $S$ :

- a person is standing on plane $S$, trying to keep a vertical posture, and their feet are set in a specified area (sometimes determined by limiters);

- force transmitters are located in apexes of any symmetrical geometric shape (usually being an equilateral triangle or a square).

In the basic version of the technical solution of a posturograph, reaction forces $P_{A}, P_{B}, P_{C}$ are measured in three points of support, by placing force transmitters in apexes of an equilateral triangle with side $a$ and apexes $A, B$ and $C$. The coordinate system starts in the centroid of plane $S$ (fig. 3).

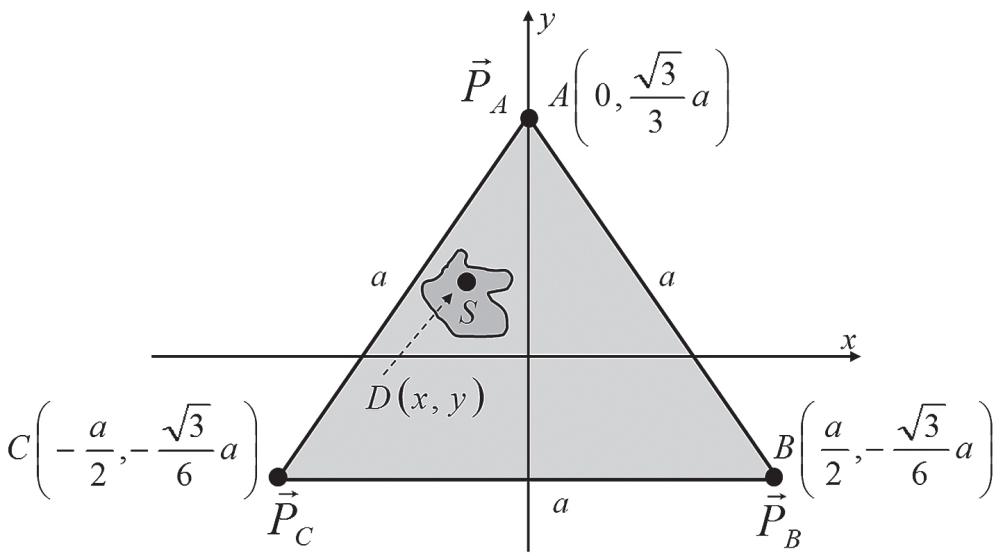

Fig. 3. Coordinate system with its beginning overlapping with the centroid of plane $\mathrm{S}$ resting on three supports $\left(\vec{P}_{A}, \vec{P}_{B}, \vec{P}_{C}\right.$ - contact forces on strain gage transmitters placed in apexes $\mathrm{A}, \mathrm{B}, \mathrm{C}$; D - momentary position of the center-of-mass projection; a-distance between strain gage transmitters)

Body mass $m$ placed on plane $S$ of an equilateral triangle impacts on it with the force:

$Q=m \cdot g$

where: $g$ - gravitational acceleration.

The direction of operation of vector $\vec{Q}$ goes through plane $S$ in point $D$ being the projection of center of mass $m$ on that plane. The following dependence is met on plane $S$ :

$$
\vec{Q}=\vec{P}_{A}+\vec{P}_{B}+\vec{P}_{C}
$$

where: $\vec{P}_{A}, \vec{P}_{B}, \vec{P}_{C}$ - contact forces on strain gage transmitters placed in apexes $A, B, C$.

The position of the projection of center of mass $m$ in the adopted coordinate system $(x, 0, y)$ lying in plane $S$ may be determined by measuring the reaction forces on supports:

$$
\begin{aligned}
& x=\frac{a}{2} \cdot \frac{\vec{P}_{B}-\vec{P}_{C}}{\vec{P}_{A}+\vec{P}_{B}+\vec{P}_{C}} \\
& y=\frac{a}{2 \sqrt{3}} \cdot \frac{\vec{P}_{A}-\vec{P}_{B}-\vec{P}_{C}}{\vec{P}_{A}+\vec{P}_{B}+\vec{P}_{C}}
\end{aligned}
$$

where: $a$-distance between the strain gage transmitters 
Relations (3) and (4) are the algorithm of determining coordinates of the projection of a center of mass.

In quantitative stabilogram data assessment, synthetic indicators are used which include:

- average deflections of the center-of-mass projection toward $x_{\text {avg }}$ and $y_{\text {avg }}$;

- average radius $R_{\text {avg }}$ of a statokinesigram;

The average statokinesigram radius (fig. 4) is calculated from the dependence:

$$
\begin{aligned}
& R_{\text {avg }}=\frac{1}{n} \sum_{i=1}^{n} d_{i} \\
& d_{i}=\sqrt{\left(x_{i}-x_{\text {avg }}\right)^{2}+\left(y_{i}-y_{\text {avg }}\right)^{2}} \\
& x_{\text {avg }}=\frac{1}{n} \sum_{i=1}^{n} x_{i} \\
& y_{\text {avg }}=\frac{1}{n} \sum_{i=1}^{n} y_{i}
\end{aligned}
$$

where: $n$ - number of measurements during a test.

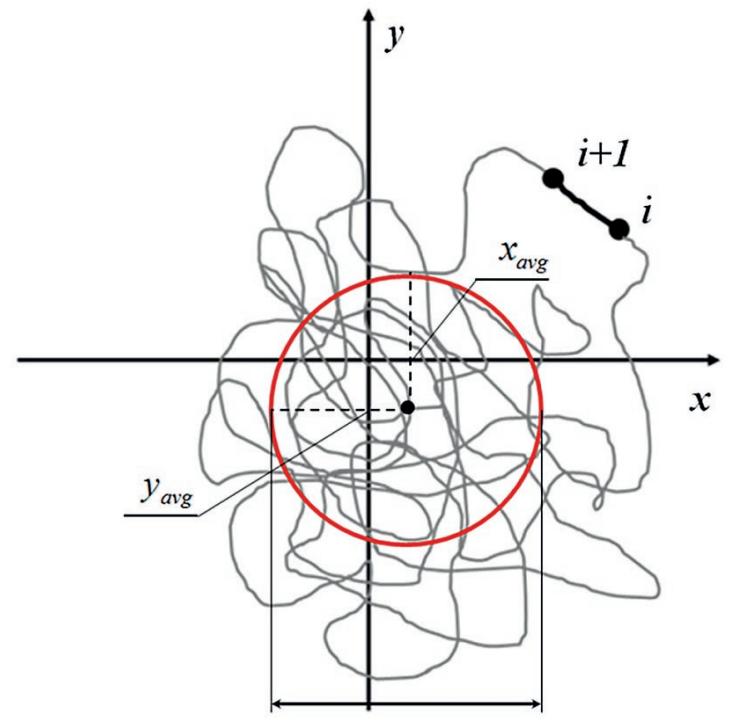

Fig. 4. Determining average radius $\mathrm{R}_{\text {avg }}$ of a statokinesigram

Such measurements are taken on appropriately prepared posturographic stations, of which main components are:

- platform consisting of a rigid base, to which strain gage transmitter bodies are fixed, for measurement of contact forces;

- strain gage sensors placed in the points of support of the rigid measurement plane.

Measurements conducted with the use of a force platform do not require any specific preparation of the examined person. 


\section{POSTUROGRAPHIC TESTS}

Quantitative information, which defines the characteristics of the balance system may be obtained by way of posturographic tests, of which scope includes:

- determining the position of the examined person's center of body mass $h$;

- determining the primary parameters defining a person's balance in a free standing posture.

Examined were nineteen candidates for fighter pilots (one woman and 18 men), students of the Polish Air Force Academy in Dęblin.

Determining the position of the examined person's center of body mass using a second-order lever (using the du Bois-Reymond's method) at the measurement station shown in figure 5. The obtained results were compiled in table 1.

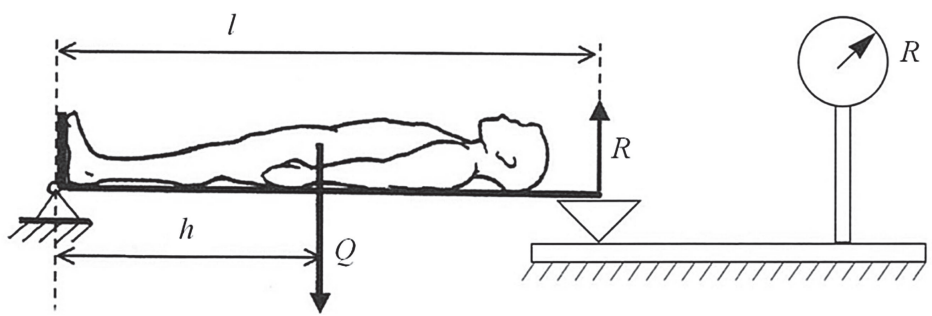

Fig. 5. Station for determining the center of mass of a person [2]

Table 1. Center-of-mass positions of the group of candidates for fighter pilots

\begin{tabular}{|c|c|c|c|c|c|}
\hline $\begin{array}{c}\text { Examined } \\
\text { person's } \\
\text { number } \\
\text { in the } \\
\text { database }\end{array}$ & Sex & $\begin{array}{c}\text { Height } \\
{[\mathrm{cm}]}\end{array}$ & $\begin{array}{c}\text { Body mass } \\
{[\mathrm{kg}]}\end{array}$ & $\begin{array}{c}\text { Body center-of-mass } \\
\text { height } \\
{[\mathrm{cm}]}\end{array}$ & $\begin{array}{c}\text { Relative height } \\
\text { of the center of body mass } \\
{[\%]}\end{array}$ \\
\hline 01 & $\mathrm{M}$ & 179.0 & 70.5 & 102.5 & 57.3 \\
\hline 02 & $\mathrm{M}$ & 183.0 & 78.0 & 102.5 & 56.0 \\
\hline 04 & $\mathrm{M}$ & 174.0 & 73.2 & 98.6 & 56.7 \\
\hline 05 & $\mathrm{~W}$ & 171.0 & 66.1 & 93.9 & 54.9 \\
\hline 06 & $\mathrm{M}$ & 162.5 & 56.3 & 92.6 & 57.0 \\
\hline 07 & $\mathrm{~W}$ & 166.0 & 64.3 & 94.3 & 56.8 \\
\hline 08 & $\mathrm{M}$ & 180.5 & 82.3 & 102.0 & 56.5 \\
\hline 09 & $\mathrm{M}$ & 179.5 & 78.2 & 101.3 & 57.7 \\
\hline 10 & $\mathrm{M}$ & 179.0 & 82.7 & 103.3 & 56.9 \\
\hline 11 & $\mathrm{M}$ & 173.5 & 74.9 & 98.8 & 57.1 \\
\hline 12 & $\mathrm{M}$ & 175.5 & 85.4 & 100.2 & 58.0 \\
\hline 13 & $\mathrm{M}$ & 175.5 & 89.6 & 101.0 & 55.9 \\
\hline 14 & $\mathrm{M}$ & 182.0 & 80.2 & 105.5 & 57.6 \\
\hline 15 & $\mathrm{M}$ & 177.5 & 92.2 & 99.3 & 56.5 \\
\hline 16 & $\mathrm{M}$ & 170.0 & 77.7 & 98.0 & 57.0 \\
\hline 17 & $\mathrm{M}$ & 167.5 & 63.8 & 94.7 & 56.1 \\
\hline 18 & $\mathrm{M}$ & 176.5 & 76.0 & 100.6 & 57.8 \\
\hline 19 & $\mathrm{M}$ & 180.0 & 76.1 & 100.9 & \\
\hline 20 & $\mathrm{M}$ & 181.5 & 84.5 & 104.9 & \\
\hline
\end{tabular}


The functional assessment of the balance system was performed using the AMTI AccuSway force platform with the Balance Clinic data processing software (fig. 6).

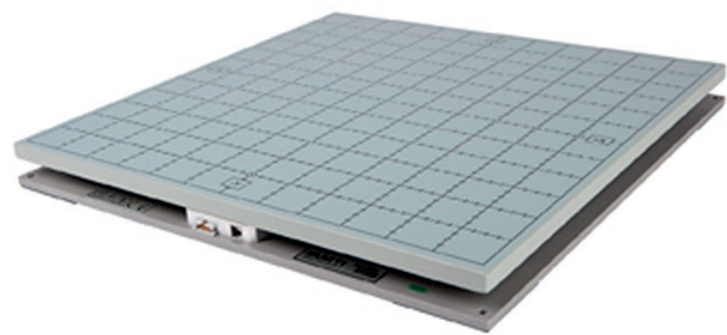

Fig. 6. View of the AMTI AccuSway platform [4]

The applied force platform with its software allows to determine the parameters, which enable an objective assessment of how the balance system functions. The analysis is conducted based on indications of strain gage sensors, which make it possible to define the movement of the center of pressure, COP, of the feet on the platform. The movement is described with components $x$ and $y$. During a single test taking 30 seconds, strain gage indications were recorded with a frequency of 50 signals per second. They constitute the basis for identifying the following parameters characterizing the examined person's ability to keep static balance:

- $\quad x$ and $y$ movement of the center of pressure, COP, off the center of the platform;

- minimum and maximum $x$ and $y$ movement off the data centroid;

- $\quad$ area of the circle covering all the measurement points in plane $X Y$;

- effective area, covering $66 \%$ of the measurement points;

- area of ellipse of 95 th percentile, which includes $95 \%$ of the measurement points, provided that their distribution is normal.

Sample entries of the posturographic measurements obtained from the Balance Clinic program are shown in figure 7.

a)

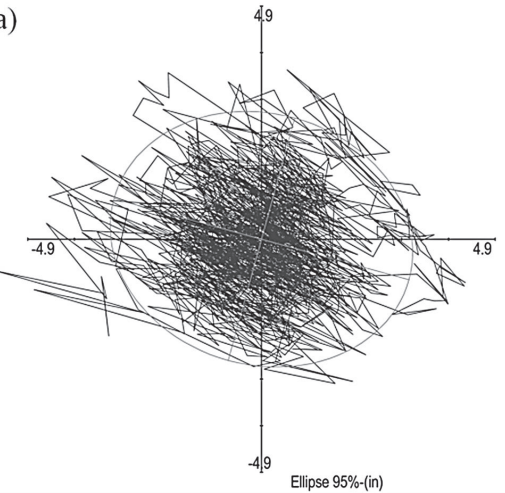

b)

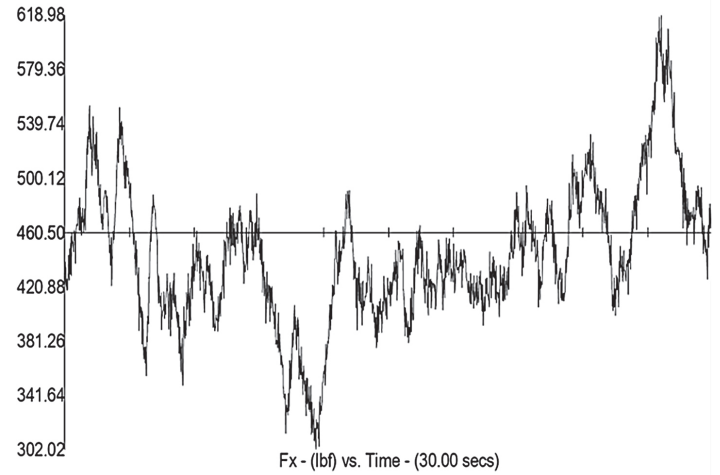

Fig. 7. Sample entries of the stabilographic measurements (a - trajectory of the center-of-pressure projection of the examined person's feet on the platform surface, $b$ - change in the contact force of the feet on the platform surface in lateral direction $\mathrm{Fx}(\mathrm{t})$ ) 
Selected parameters characterizing the functioning of the balance systems of the nineteen candidates for fighter pilots are listed in table 2.

Based on the conducted measurements of changes to the body mass center position in time, the balance system functioning was assessed. The analysis was based on the assumption that a person's balance model is a reverse pendulum [1]. Assessing the temporary deviations from a vertical position requires recording of the angle of its inclination against the one that is normal for the support plane. In the performed tests, it was assumed that a human body could be treated as a material point, and the pendulum length (height) was equal to the height of the center of body mass. The average angular deviation $\alpha$ of the pendulum was determined from the dependence:

$$
\alpha=\operatorname{arctg} \frac{R_{\text {avg }}}{h}
$$

where: $R_{a v g}$ - average of the radial vector position of the center-of-mass projection on the supporting plane calculated from the dependence (5), $h$ - height of the center of mass of the examined person's body (for standing posture).

For very low values of angle $\alpha$, it may be assumed that:

$$
\operatorname{arctg} \frac{R_{a v g}}{h} \approx \frac{R_{a v g}}{h}=\alpha
$$

Table 2. Selected results of the stabilographic measurements of candidates for fighter pilots

\begin{tabular}{|c|c|c|c|c|c|c|}
\hline $\begin{array}{c}\text { Examined } \\
\text { person's } \\
\text { number } \\
\text { in the } \\
\text { database }\end{array}$ & $\begin{array}{c}\text { Average } x \\
\text { movement off } \\
\text { platform center } \\
{[\mathrm{mm}]}\end{array}$ & $\begin{array}{c}\text { Average } y \\
\text { movement off } \\
\text { platform center } \\
{[\mathrm{mm}]}\end{array}$ & $\begin{array}{c}\text { Length } \\
\text { of the vector } \\
\text { average } \\
\text { radial } \\
\text { position } \\
{[\mathrm{mm}]}\end{array}$ & $\begin{array}{c}\text { Area of circle } \\
\text { covering 100\% } \\
\text { of data points } \\
{\left[\mathrm{mm}^{2}\right]}\end{array}$ & $\begin{array}{c}\text { Effective area } \\
\text { covering 66\% } \\
\text { of the measurement } \\
\left.\text { points [mm }{ }^{2}\right]\end{array}$ & $\begin{array}{c}\text { Area of the } \\
\text { ellipse } \\
\text { of 95\% } \\
\text { percentile } \\
{\left[\mathrm{mm}^{2}\right]}\end{array}$ \\
\hline 01 & $x_{\text {avg }}$ & $y_{\text {avg }}$ & $R_{\text {avg }}$ & $A_{\text {circ }}$ & $A_{\text {effect }}$ & $A_{95}$ \\
\hline 02 & -46.11 & 27.14 & 4.39 & 279.72 & 79.69 & 222.47 \\
\hline 04 & -43.91 & 28.05 & 2.43 & 100.68 & 24.05 & 68.97 \\
\hline 05 & -37.32 & 26.05 & 2.28 & 101.39 & 23.34 & 59.76 \\
\hline 06 & -45.99 & 26.22 & 2.66 & 115.01 & 28.90 & 77.09 \\
\hline 07 & 50.11 & 27.57 & 3.36 & 212.46 & 48.85 & 116.62 \\
\hline 08 & -53.25 & 26.56 & 4.20 & 273.30 & 75.89 & 192.69 \\
\hline 09 & -40.03 & 26.69 & 3.54 & 159.28 & 53.55 & 115.52 \\
\hline 10 & -55.28 & 26.92 & 4.20 & 96.84 & 20.56 & 54.85 \\
\hline 11 & -54.56 & 26.465 & 5.34 & 490.38 & 123.69 & 324.211 \\
\hline 12 & -45.29 & 26.817 & 2.05 & 081.46 & 17.72 & 46.79 \\
\hline 13 & -42.57 & 26.069 & 2.67 & 130.61 & 29.58 & 84.55 \\
\hline 14 & -38.59 & 25.43 & 3.50 & 220.26 & 53.72 & 149.13 \\
\hline 15 & -44.11 & 26.14 & 2.96 & 170.50 & 38.78 & 98.45 \\
\hline 16 & -54.475 & 25.69 & 4.96 & 419.00 & 104.31 & 279.55 \\
\hline 17 & -50.604 & 27.79 & 4.42 & 321.63 & 84.23 & 227.27 \\
\hline 18 & -41.49 & 26.85 & 2.35 & 100.55 & 23.24 & 63.99 \\
\hline 19 & -43.60 & 26.40 & 3.33 & 178.98 & 45.40 & 133.54 \\
\hline 20 & -47.68 & 26.43 & 3.41 & 169.24 & 49.79 & 123.94 \\
\hline & & & & & & \\
\hline
\end{tabular}


The average values of deviation angle $\alpha$ for the nineteen examined persons are shown in table 3 .

Table 3. Average angle of center-of-mass deviation $\alpha$ off the data centroid $\left(x_{\text {avg }}, y_{\text {avg }}\right)$

\begin{tabular}{|c|c|c|c|}
\hline $\begin{array}{l}\text { Examined } \\
\text { person's number } \\
\text { in the database }\end{array}$ & $\begin{array}{l}\text { Length of the vector average radial } \\
\text { position }[\mathrm{mm}]\end{array}$ & $\begin{array}{l}\text { Body center-of-mass } \\
\text { height }[\mathrm{cm}]\end{array}$ & $\begin{array}{l}\text { Average deviation } \\
\text { angle [rad] }\end{array}$ \\
\hline & $R_{a v g}$ & $h$ & $\alpha=R_{\text {avg }} / h$ \\
\hline 01 & 4.39 & 102.5 & 4.28 E-03 \\
\hline 02 & 2.43 & 98.3 & 2.36 E-03 \\
\hline 04 & 2.28 & 98.6 & $2.31 \mathrm{E}-03$ \\
\hline 05 & 2.66 & 93.9 & $2.83 \mathrm{E}-03$ \\
\hline 06 & 3.36 & 92.6 & $3.63 \mathrm{E}-03$ \\
\hline 07 & 4.20 & 94.3 & 4.46 E-03 \\
\hline 08 & 3.54 & 102.0 & 3.47 E-03 \\
\hline 09 & 2.20 & 101.3 & $2.19 \mathrm{E}-03$ \\
\hline 10 & 4.27 & 103.3 & $4.13 \mathrm{E}-03$ \\
\hline 11 & 5.34 & 98.8 & $5.41 \mathrm{E}-03$ \\
\hline 12 & 2.05 & 100.2 & $2.05 \mathrm{E}-03$ \\
\hline 13 & 2.67 & 101.0 & $2.64 \mathrm{E}-03$ \\
\hline 14 & 3.50 & 105.5 & 3.32 E-03 \\
\hline 15 & 2.96 & 99.3 & $2.98 \mathrm{E}-03$ \\
\hline 16 & 4.96 & 98.0 & $5.06 \mathrm{E}-03$ \\
\hline 17 & 4.42 & 94.7 & 4.66 E-03 \\
\hline 18 & 2.35 & 100.6 & $2.34 \mathrm{E}-03$ \\
\hline 19 & 3.33 & 100.9 & $3.30 \mathrm{E}-03$ \\
\hline 20 & 3.41 & 104.9 & 3.25 E-03 \\
\hline
\end{tabular}

The analysis of the average radial length of the position of center-of-mass projection $R_{\text {avg }}$ referred to height $h$ has proven that angle $\alpha=\operatorname{arc} \operatorname{tg}\left(R_{\text {avg }} / h\right) \approx R_{\text {avg }} / h$ clearly differentiates the results obtained by the individual examined persons, which is shown in table 4 and in fig. 8 .

The examined person, who was assigned number 12 in the database has demonstrated the highest ability to keep a stable posture $\left(\alpha_{\min }=0.00205 \mathrm{rad}\right)$. For the subsequent persons, angle $\alpha$ gets bigger and bigger, which means a decline in that ability. The highest value of that angle in the examined group of candidates for fighter pilots $\alpha_{\max }=0.00541 \mathrm{rad}$ (obtained by the person with number 11 in the database) is over twice as high as $\alpha_{\min }$.

The angles of deviation of the examined person's center of gravity off the neutral position, determined during the posturographic measurements, are small, but their values determined in further tests carried out for all the static balance test participants differ considerably. The method selectivity indicator $s$, defined as a quotient of the range of measurement results to their average value,

$$
s=\frac{\left(\alpha_{\max }-\alpha_{\min }\right)}{\frac{1}{n} \sum_{i=1}^{n} \alpha_{i}}
$$

has a high value, $s=0.9$, for the data compiled in table 4 . 
Table 4. The angles of center-of-mass deviation $\alpha$ off the data centroid $\left(x_{\text {avg }}, y_{\text {avg }}\right)$ structured in the range $\alpha_{\min }-\alpha_{\max }$

\begin{tabular}{|c|c|c|}
\hline & \begin{tabular}{c|} 
Examined \\
person's \\
identification \\
number \\
\end{tabular} & Angle of inclination $\alpha$ [rad] \\
\hline 1 & 12 & $2.05 \mathrm{E}-03$ \\
\hline 2 & 09 & 2.19E-03 \\
\hline 3 & 04 & $2.31 \mathrm{E}-03$ \\
\hline 4 & 18 & $2.34 \mathrm{E}-03$ \\
\hline 5 & 02 & $2.38 \mathrm{E}-03$ \\
\hline 6 & 13 & $2.64 \mathrm{E}-03$ \\
\hline 7 & 05 & $2.83 \mathrm{E}-03$ \\
\hline 8 & 15 & $2.98 \mathrm{E}-03$ \\
\hline 9 & 20 & $3.25 \mathrm{E}-03$ \\
\hline 10 & 19 & $3.30 \mathrm{E}-03$ \\
\hline 11 & 14 & $3.32 \mathrm{E}-03$ \\
\hline 12 & 08 & $3.47 \mathrm{E}-03$ \\
\hline 13 & 06 & $3.63 \mathrm{E}-03$ \\
\hline 14 & 10 & 4.13E-03 \\
\hline 15 & 01 & $4.28 \mathrm{E}-03$ \\
\hline 16 & 07 & $4.46 \mathrm{E}-03$ \\
\hline 17 & 17 & $4.66 \mathrm{E}-03$ \\
\hline 18 & 16 & $5.06 \mathrm{E}-03$ \\
\hline 19 & 11 & $5.41 \mathrm{E}-03$ \\
\hline
\end{tabular}

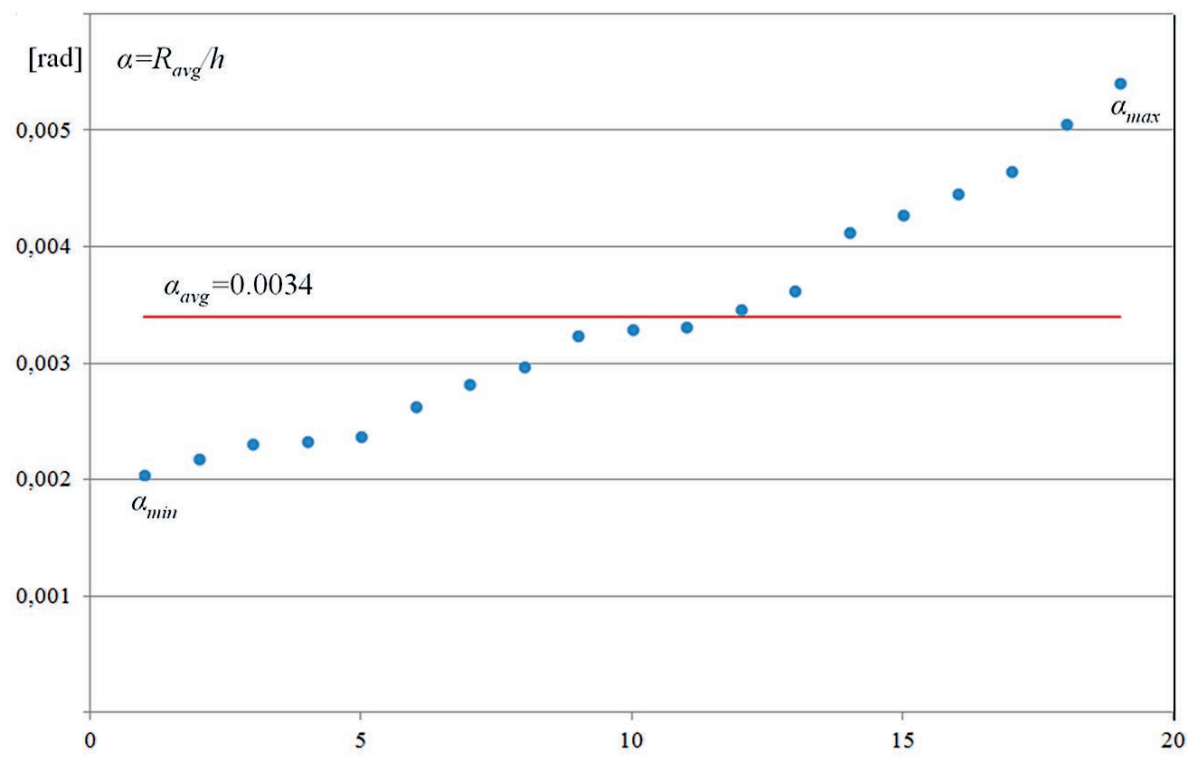

Fig. 8. The angles of center-of-mass deviation $\alpha$ off the data centroid $\left(x_{\text {avg }}, y_{\text {avg }}\right)$ structured in the range $\alpha_{\min }-\alpha_{\max }$ 


\section{SUMMARY}

Candidates for military pilots undergo detailed medical examinations and specialized tests verifying their physical and mental qualifications at the Military Institute of Aviation Medicine (WIML) in Warsaw. After completing the recruitment process for the first year of instruction at the Polish Air Force Academy in Dęblin, there is an additional qualification of the persons admitted to the three specialties: piloting jet aircraft (PSO), helicopters (PŚm) and cargo aircraft (PSTr). During the first academic year, aviation training is held at the Academic Aviation Training Center (AOSzL) pursuant to the civil regulations, which ends in obtaining a professional license of a cargo aircraft pilot (PSTr) and a tourist pilot license in the (PSO) or (PŚm) specialties. The next stage is piloting military aircraft.

The highest ability to maintain spatial orientation must be demonstrated by pilots of jet aircraft (fighter and attack aircraft) because of the highest ceiling, high speeds and gravity loads they experience during maneuvers they perform. Pilots of helicopters also need to have good orientation in space, however, because of a lower ceiling and speed, requirements in this respect may be somewhat lower. Military cargo aviation differs from civil aviation only in the type of load, and by its nature is focused on a stable and safe flight. That is why piloting those aircrafts is easier than piloting high-maneuvering planes, and available to all students of the Polish Air Force Academy.

The process of selecting the candidates for training in piloting (high-maneuvering) jet aircraft may be supported by posturographic tests, which allow for a quantitative assessment of the qualifications to keep balance in quasi-static conditions. It is an individual trait, which may be improved through appropriate training and subsequent aviation experience only to a limited extent.

The presented results of the tests held for the nineteen candidates offer a possibility to select a group of people with the highest ability to keep static balance It may be assumed that eleven people, whose results of postural balance stability tests are below the average value of angle $\alpha_{\text {avg }}$ (fig. 8) have the highest qualifications to pilot jet aircrafts (PS).

It should also be emphasized that the described verification test is relatively inexpensive and to be completed over a few minutes. It may be considered an additional criterion (of a quantitative nature) in the complex process of selecting the candidates to be trained for the most difficult type of piloting, i.e. fighter and attack aircraft aviation.

\section{LITERATURE}

[1] Błaszczyk, J., 2004, Biomechanika kliniczna (Clinical Biomechanics), Wydawnictwo Lekarskie PZWL, Warszawa.

[2] Bober, T. and Zawadzki, J., 2001, Biomechanika układu ruchu człowieka (Biomechanics of the human movement system), Wydawnictwo BK, Wrocław.

[3] Golema, M., 2002, Charakterystyka procesu utrzymania równowagi ciała człowieka w obrazie stabilograficznym (Characterization of the process of maintaining the balance of the human body in a stabilographic image), Wydawnictwo AWF, Wrocław. 
[4] http://www.technomex.pl/platformy-diagnostyczno-rehabilitacyjne/platformy-stabilometryczne/ accu-sway-platforma-dynamograficzna-do-oceny-rownowagi

[5] Winter, D. A., 1995, Human balance and posture control during standing and walking, Gait \& Posture, Vol. 3, pp. 193-214.

[6] Opara, T. and Preibish, P., 2001, Computerized stabilography as diagnostic tool for selected cases of curvature of the backbone, VI-th International Conference CADSM 2001, Proceedings - Publishing House of Lviv Polytechnic National University, pp. 265-268.

[7] Opara, T., Preibish, P. and Iwanejko, L., 2002, Determination of Synthetic Parameters Characterizing the Human Balance in Static Conditions, TCSET'2002, Proceedings-Publishing House of Lviv Polytechnic, pp. 315-319.

[8] Opara, T. i Preibish, P., 2001, Określenie parametrów charakteryzujacych statokinetyczna równowage czlowieka (Determination of parameters characterizing the statokinetic human balance), V Szkoła - Konferencja MWK'2001 Metrologia Wspomagana Komputerowo, materiały: sekcja VI - Inne Zastosowania Metrologii, tom 2, str. 335-342.

[9] Nowak, S., 2005, Sterowanie pozycja stojaca w procesie wychowania fizycznego (The controlling of upright position in the process of physical education), Wydanie I, Zakład Poligraficzny Politechniki Radomskiej, Radom, ISSN 1642-5278.

[10] Masłowski, W., Opara, T. and Burek, M., 2016, Posturogrphic examination of candidates for militay pilots, I Kongres Lotniczy i Kosmonautyczny, Rzeszów, Streszczenia referatów, str. 73-75.

\section{BADANIA POSTUROGRAFICZNE KANDYDATÓW NA PILOTÓW WOJSKOWYCH}

\section{Streszczenie}

Jednym z wielu elementów procesu kwalifikacji kandydatów na pilotów wojskowych statków powietrznych jest ocena poprawności funkcjonowania ich systemu utrzymania równowagi, odpowiedzialnego między innymi za orientację przestrzenną w trakcie lotu. Układ ten w sposób ciągły kontroluje położenie przestrzenne środka masy ciała. Bezpośredni pomiar tej wielkości jest złożonym zadaniem metrologicznym. $\mathrm{Z}$ tego powodu, w badaniach stabilności postawy stojącej stosuje się miarę zastępczą, którą jest położenie rzutu środka masy na płaszczyźnie podparcia.

Informację ilościową określającą właściwości układu utrzymania równowagi można uzyskać poprzez badania posturograficzne, które obejmują pomiar, rejestrację i ocenę trajektorii rzutu środka masy ciała osoby badanej.

We wstępnym etapie przebadano dziewiętnastu kandydatów na pilotów samolotów odrzutowych (jedną kobietę i 18 mężczyzn) - studentów Wyższej Szkoły Oficerskiej Sił Powietrznych w Dęblinie.

W oparciu o przeprowadzone pomiary położenia środka masy ciała oraz badania stabilograficzne dokonano oceny poprawności funkcjonowania ich układu równowagi. W artykule omówiono metodę badań, przedstawiono wyniki pomiarów oraz wnioski.

Słowa kluczowe: posturografia, położenie środka masy ciała, układ równowagi, platforma stabilograficzna. 